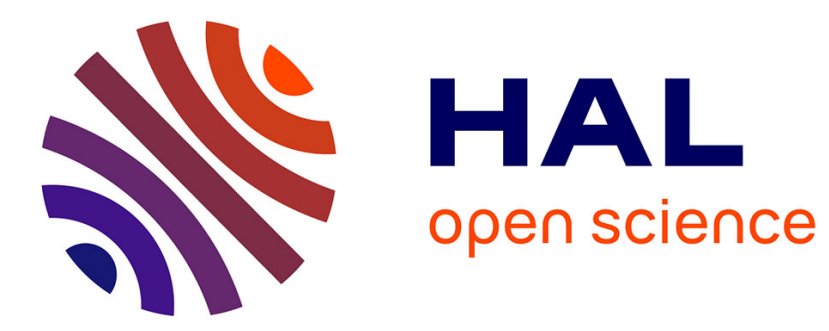

\title{
Multidisciplinary analysis of protein-lipid interactions and implications in neurodegenerative disorders
}

F. Collin, O. Cerlati, F. Couderc, B. Lonetti, J.-D. Marty, A.-F. Mingotaud

\section{To cite this version:}

F. Collin, O. Cerlati, F. Couderc, B. Lonetti, J.-D. Marty, et al.. Multidisciplinary analysis of proteinlipid interactions and implications in neurodegenerative disorders. Trends in Analytical Chemistry, 2020, 132, pp.116059. 10.1016/j.trac.2020.116059 . hal-03430081

\section{HAL Id: hal-03430081 https://hal.science/hal-03430081}

Submitted on 16 Nov 2021

HAL is a multi-disciplinary open access archive for the deposit and dissemination of scientific research documents, whether they are published or not. The documents may come from teaching and research institutions in France or abroad, or from public or private research centers.
L'archive ouverte pluridisciplinaire HAL, est destinée au dépôt et à la diffusion de documents scientifiques de niveau recherche, publiés ou non, émanant des établissements d'enseignement et de recherche français ou étrangers, des laboratoires publics ou privés. 


\title{
Multidisciplinary analysis of protein-lipid interactions and implications in neurodegenerative disorders
}

\author{
F. Collin*, O. Cerlati, F. Couderc, B. Lonetti, J.-D. Marty, A.-F. Mingotaud \\ Laboratory IMRCP, CNRS UMR 5623, University Paul Sabatier, Toulouse, France
}

*corresponding author: University Paul Sabatier - Toulouse III, Laboratory IMRCP, CNRS UMR 5623, 118 route de Narbonne, 31062 Toulouse Cedex 09, email : fabrice.collin@univtlse3.fr

\begin{abstract}
Alzheimer's disease (AD) is the most common cause of dementia in the elderly. Considerable effort is currently made by scientists to understand the molecular mechanisms underlying its development, but no clear answer has been attained yet. One reason might be that the needed multidisciplinarity of this type of research is pushed to extreme conditions. Among the mechanisms identified, protein-lipid interaction could play an important role. Understanding these interactions is crucial, and multiple approaches have been developed which have led to increased knowledge in this area.

This review, focusing over the last 10 years, presents how techniques spanning from analytical chemistry to physical chemistry help assessing protein-lipid interaction in AD. It focuses on proving its existence, identifying the sites of interaction, and understanding the consequences such interaction would have regarding further evolution of the protein and the lipid. Finally, it shows that understanding protein-lipid interaction in AD effectively requires multi-technique-based strategies.
\end{abstract}

\section{Keywords}

Self-assembly, beta-amyloid, neurodegenerative disease, microscopy, spectroscopy, scattering, biomolecule. 


\section{Introduction}

Lipids are the most abundant organic compounds in the brain and changes in their concentration, organization and metabolism are associated with several diseases. The term "lipids" refers to a wide variety of molecules, including fatty acids, glycerophospholipids, triacylglycerols, sphingolipids, sterols (Figure 1) and biosynthetically or functionally related compounds[1]. Lipids are mainly found in biological membranes - a meeting point for proteins and lipids - where they participate in control of protein function and regulation of membrane trafficking. They are also involved in Amyloid Precursor Protein (APP) processing, the bloodbrain barrier function, membrane remodeling, myelination, oxidation, inflammation and energy balance[2]. Protein-lipid interaction plays an important role in biological functions of cells, and might be, as such, also involved in the development of diseases. In neurodegenerative diseases for example, lipids are known to trigger the aggregation of $\alpha$-synuclein or $\beta$-amyloid peptides, in relation with Parkinson's or Alzheimer's disease, respectively. Protein-lipid interaction might also refer to modification of protein by lipid, called protein lipidation, and is either involved in lipidation-mediated cell signaling or associated with several diseases, as for example atherosclerosis[3]. Such a covalent modification of protein and its characterization will not be discussed in this review.

In Alzheimer's disease (AD), abnormal protein deposits are found in amyloid plaques and neurofibrillary tangles, the two defining neuropathological characteristics of the disease. They are composed respectively of the $\beta$-amyloid peptide (A $\beta)$, a 40 to 42 amino acids long peptide - generated by the cleavage of the transmembrane APP - able to aggregate into fibrils, and of the full-length microtubule-associated protein Tau - normally involved in microtubule assembly and stabilization - hyperphosphorylated, which arranges into paired helical filament (PHF)[4]. The link between $A \beta$ aggregation-deposition in senile plaques in brain tissue and neurodegeneration in AD is known as the amyloid hypothesis, proposed 30 years ago. The extended amyloid cascade hypothesis, which includes also Tau pathology, remains still controversial on some parts[5,6]. The amyloid hypothesis has become the focus of much AD research, and $A \beta$ or Tau interaction with membrane lipids was, in particular, under focus.

Both $A \beta$ and Tau share intrinsic affinity for lipids, in particular for negatively charged ones (Figure 1). The C-terminal moiety of $\mathrm{A} \beta$ comes from the part within APP that is buried in the phospholipid bilayer (cleaved by $\gamma$-secretase), while the $\mathrm{N}$-terminal one is hydrophilic (cleavage of the extracellular part of APP by $\beta$-secretase). The Tau protein wears in its sequence four repeats in charge of binding with microtubule and two hydrophobic hexapeptides, PHF6 and PHF6* (Figure 1). It is able to form stable complexes with phospholipids in a phosphorylation-dependent manner by interactions involving both the microtubule-binding and the projection (N-terminal) domains [7]. In both cases, interaction with membrane lipids modulates the way $\mathrm{A} \beta$ and Tau aggregate into $\beta$-sheet-rich fibrils, protein aggregation and misfolding being one of the important features of neurodegenerative diseases. $\mathrm{A} \beta$ is able to either insert into the phospholipid membrane or to bind onto its surface, or both; the mechanism is driven by electrostatic and hydrophobic interactions and thus depends on the lipid constitution of the membrane, crucial in dynamic regulation of $A \beta$ aggregation pathways[8]. The nature of the interaction is important since binding often leads to the 
acceleration of fibrils formation, unlike insertion, which can trigger the membrane permeabilization by forming ion channel-like structures (Figure 1). Cholesterol and GM1 gangliosides are two other key-factors affecting $A \beta$ fibrillation on membrane[9]. More generally, protein-lipid interaction depends on several properties of both membrane surface (hydrophobicity, electrostatic surface potential, density of lipid packing, curvature, etc.) and protein (chemical structure, hydrophobicity and net charge, the way it interacts with the surface, stability of conformational states, etc.).

In this context, what is relevant to study and how to do it? What is the required information to better understand the mechanisms underlying $A \beta$ and Tau interaction with membrane and subsequent aggregation? For studying protein-lipid interaction, laboratory membrane systems are often used, as they make it possible to overcome the excessive complexity of cell membranes, while remaining representative for the study of specific phenomena. At this point, it should be mentioned that the scientific information provided by these studies remain only indicative and hints towards what may happen in vivo[10,11]. One therefore should be very cautious not to over-interpret some of the results here. Most studies are performed on model systems: two different families can be distinguished: i) supported lipid membranes (SLM) or supported lipid bilayer (SLB) acting as model membranes which are planar lipid membranes adsorbed onto a solid support and which mimic the natural cell membrane separating the extracellular and intracellular fluids of the living cell, ii) liposomes or vesicles (small, large, giant, multilamellar, etc.) which are stable colloids in solution. Other systems are micelles, black lipid membranes, lipid monolayers, bicelles, or nanodiscs[12]. As the lipid composition and the physical properties of the membrane model system significantly influences the interaction of the protein and its future evolution, the choice of the model is crucial. The analytical techniques to be implemented then depend on the required information: to prove the existence of an interaction, to localize the interacting sites or to elucidate the consequences of the interaction on the future evolution of either the lipid or the protein. In this review, we will focus on the techniques themselves and sort them according to the above class of information they can provide, even if some of them do not easily fit into one unique class. For each, we will provide the information that can be obtained, followed by assets and disadvantages. The reader should keep in mind that the objective of this review is not to give the latest results linked to protein-lipid interaction in Alzheimer's disease but to present an overview of all techniques available to do this.

\section{Proving the existence of an interaction}

In order to understand the mechanisms involved in disease pathogenesis, different approaches have to be developed, one of them being identification of lipid-protein interactions - Information on the existence of such interactions with corresponding kinetic and thermodynamic parameters can be inferred by using various analytical techniques. Some of them give directly the searched information, while others require the use of an appropriate model from which the parameters of interest are extracted.

A first set of techniques enables to infer information on the interaction without specific modification of the partners of the association. Hence, Atomic Force Microscopy (AFM) is a technique of choice to study and visualise, thanks to a mechanical probe, a surface and its 
modification with resolution below nanometer scale (Figure 2A). Interestingly, AFM does not require any labelling or staining and can be operated under physiological relevant conditions. Using time-lapse AFM, it is further possible to image assembling process of proteins[13-15]. With this technique, Tau protein self-assemblies were evidenced on SLM. These assemblies are prone to grow depending on Tau concentration in buffer solution and on the nature of cationic species in solution: whereas $\mathrm{Na}^{+}$promotes the formation of aggregates, $\mathrm{K}^{+}$tends to disassemble them[16]. Tau structural compaction and membrane-induced disruption was also evidenced by studying the modification of Langmuir film isotherms of an anionic lipid monolayer by the addition of Tau base protein[17] or peptide[18]. In addition, the kinetic of protein interactions with membranes can be assessed in real time by using Quartz Crystal Microbalance with Dissipation monitoring technique (QCM-D)[19]. This technique enables to measure mass uptake/loss at the sensor surface in real-time by measuring the modification of piezoelectric properties of gold surfaces upon which SLM are deposited (Figure 2A). Like AFM, QCM-D does not require any labelling. For instance, QCM-D experiments enabled to evidence an adsorption behaviour of $\mathrm{A} \beta$ peptide onto SLMs which was concentrationdependent[20]. Isothermal Titration Calorimetry (ITC) allows measuring the thermodynamic parameters of the interaction (Figure 2A). It enables, from the analysis of binding isotherm obtained by sequential addition of protein upon a solution of model membranes, to calculate the affinity $\left(K_{d}\right)$, enthalpy $(\Delta H)$, entropy $(\Delta S)$, and change in specific heat capacity $\left(\Delta C_{p}\right)$ of the interaction. ITC is compatible with turbid and heterogeneous samples and does not require labelling. Hence, ITC was successfully used to study the affinity between different Tau segments and anionic and neutral membranes of small unilamellar vesicles: while neutral membranes exhibited weak interactions with each Tau repeat segment, a stronger binding with anionic membranes of some Tau segments was observed[21]. ITC was also exploited to assess the effect of membrane curvature of small liposomes on amyloid aggregation[22,23] and to monitor the change in supramolecular organization (appearance or disruption of a bilayer) induced by the presence of protein[24]. Lastly mass spectrometry coupled with ion mobility spectroscopy (IM-MS) has enabled to identify interaction of protein with different lipidic compounds, and thus has given an indirect evidence of protein-lipid interaction (Figure 2C) [25].

Other methods, like fluorescence or confocal microscopy, require first to label the protein before measurement. They have been extensively used to highlight existing interactions and/or aggregation phenomenon. Nevertheless, their main drawbacks are related to their poor resolution typically in the micrometer range. The level of obtained information can be increased by using Fluorescence Correlation Spectroscopy (FCS) which analyzes the Brownian motion of fluorescent systems: when an interaction occurs the diffusion rate of the probe decreases and by using specific model one can infer additional data on the studied interaction (Figure 2A). Thanks to FCS, it was demonstrated that the presence of $\mathrm{A} \beta$ specific sequences promote aggregation of $A \beta$ in membranes on living cells at physiological nanomolar concentration[26]. Similarly, the presence of Tau protein fragments in a lipid bilayer promoted the formation of aggregates if this concentration exceeds a critical level[27]. Additionally, fluorescence is environment-dependent and an energy transfer may occur between appropriate fluorophores (close in space), called Förster (or Fluorescence) Resonance Energy Transfer 
(FRET). This method has been used to evidence protein/lipid interactions (Figure 2A) [28,29] and to give information on protein conformation upon interaction with lipids [30].

\section{Localization of the interaction sites}

Knowledge of the location of the interaction site is essential since protein action might be hampered or modified depending on this site. This can be assessed by introducing labeled parts that can be tracked by different techniques such Electron Paramagnetic Resonance (EPR). For instance, Eliezer and coll. presented several studies where domains of the Tau protein were modified and this showed that, if the R2 part was the most important one to generate aggregates with lipids, the N-terminal projection domain was also involved[7]. His team also performed an elegant study with doubly spin-labelling to examine the long-range architecture of the Tau protein[31]. Spin-labelled lipids were also employed to show by EPR analysis that the short $A \beta_{25-35}$ model peptide is having two behavior when interacting with model membrane systems: a first population inserts the bilayer and a second one is weakly coupled to its surface[32]. Therefore, people have consistently examined the possibility to directly analyze the protein/lipid interaction. Nuclear Magnetic Resonance (NMR), InfraRed (IR) or Raman experiments are common techniques used for analyzing interaction between molecules. However, if this is usually quite simple for small molecules, the complexity of protein/membrane systems is such that it is essential to adopt one of the two following strategies. First, it is possible to make the system simpler by using models of the proteins (i.e. parts of it) or models of the biological membrane (i.e. synthesized lipid self-assemblies such as micelles or liposomes)[33]. Secondly, one may develop new protocols for each technique, and this is particularly true for NMR, the development of which has been tremendous linked to biology.

Typical NMR analysis of protein/lipid interaction implies high resolution in order to identify the appropriate signals. Different conditions are used, from solution to solid state, as well as all possible nuclei from ${ }^{1} \mathrm{H},{ }^{13} \mathrm{C},{ }^{15} \mathrm{~N}$ or ${ }^{31} \mathrm{P}$. A first level of NMR clearly identifies which part of the protein is modified in the presence of a membrane or membrane model through signal widening and possible disappearance (Figure 2B). This has been performed in an efficient manner for protein/micelles systems and showed that the C-terminal part of $\mathrm{A} \beta$ disappeared inside the micelle[33]. In the case of liposomes, direct high resolution NMR is however impossible, due to the large number of lipid molecules leading to slow molecular tumbling, fast transverse relaxation times, and line broadening of NMR resonances. Indirect methods have thus to be used in this case and various sequences have been developed for this, based on cross-correlation such as dipolar-assisted rotational resonance (DARR) [7,34,35]. Identification of the different amino acids in the protein has thus to be known and the signals are compared to those observed in the presence of the lipidic system. The data treatment can then highlight which amino acid is concerned by the interaction by the modification of its signal. A recent study on Tau-phospholipid oligomeric complexes by Elezier is a remarkable example of such a strategy, as it shows that the residues forming the oligomer core are located in the R2 and R3 repeat domain of Tau, and include PHF6 and PHF6*[7]. In a more general way, solid state NMR can also be indicative of morphological changes in the presence of lipid bilayers, as indicated for instance in Yang's work on $A \beta$. The structure model of $A \beta_{40}$ fibrils in solution was found to contain parallel $\beta$-strands while nonparallel $\beta$-strands and kink were 
observed in the presence of lipid vesicles[8]. Heteronuclear correlation experiments, such as 2D ${ }^{1} \mathrm{H}-{ }^{15} \mathrm{~N}$ TROSY (transverse relaxation optimized spectroscopy), can also provide detailed insight into protein-lipid interaction and was used to show that only small groups of Tau residues, from the repeat regions, interact with microtubules[36]. NMR spectrometry has established itself as an essential technique for the characterization of proteins and has the advantage of working on the native protein (or part of it).

Mass spectrometry is another technique allowing identifying the interaction sites. The mass spectrometric-based methods enabling the characterization of peptides, proteins or selfassemblies only appeared in the late 90s but the progress made is now opening up tremendous opportunities in the field of protein/lipid interactions among others. Several strategies have been developed to either analyze directly large molecules and self-assemblies, by native-MS, or indirectly through crosslinking which forms a link between interacting species. This thus enables to examine which groups were interacting with each others [37,38]. The recent study of Zweckstetter, based on crosslinking by amine groups of mixtures of Tau protein and microtubules or tubulin dimers followed by electrospray mass ionization-MS analysis, established which lysine residues were involved in the interaction (Figure 2B) [36]. Information can also be obtained indirectly by bottom-up or top-down proteomics or by hydrogendeuterium exchange mass spectrometry (HDX-MS)[38]. The literature is scarce regarding the use of HDX-MS for studying lipid interaction with amyloidogenic proteins, in particular with $A \beta$. An example can be given with another amyloidogenic protein, serum amyloid A (SAA) protein, not connected to $\mathrm{AD}$ but that is, like $\mathrm{A} \beta$, susceptible of aggregating upon lipid interaction. HDX-MS was very recently used to reveal the POPC-binding sites of SAA and to show lipid-induced folding of one $\alpha$-helix part of SAA[39]. This result is interesting as a perspective of using HDX-MS for studying A $\beta$-lipids interaction.

\section{Consequences of protein-lipid interaction}

From the medical standpoint, this is the part of outmost expectations. Being able to establish what are the consequences of protein-lipid interaction enables to sort out what parameters have an influence on the outcome of the disease. In AD, the early oligomeric forms of $A \beta$ are recognized to be the most toxic species [40]. Understanding the effects of the interaction of these species with cellular membrane is not straightforward: (i) the pathogenic protein pre-fibrillar assemblies can bind to cell membrane components inducing clustering and toxicity; (ii) on the other hand, the interaction of misfolded proteins with membrane components can select a particular conformer which is prone to molecular clustering and aggregation and increases their local concentration. In any case, the consequences of the interaction are the change of membrane physico-chemical properties and geometry until loss of membrane integrity.

\subsection{Probing protein conformation and aggregation}

Different experimental techniques have been used in order to finely characterize the assemblies which can form in proximity of a biological surface and analyse the difference from what happens in bulk solution. In particular, attention is addressed to the nature of the secondary structure of proteins and the structural characteristic of aggregates. For this purpose, 
Circular Dichroism (CD) is a technique of choice since protein secondary structure has characteristic fingerprints in the far UV dichroic spectra (Figure 2C). A negative peak at around $195 \mathrm{~nm}$ is typical of random coil conformations, $\alpha$-helix have negative bands at $222 \mathrm{~nm}$ and $208 \mathrm{~nm}$ and a positive peak at $193 \mathrm{~nm}$; while a negative and positive peak at $218 \mathrm{~nm}$ and 195 $\mathrm{nm}$ respectively corresponds to $\beta$-sheet conformations[41]. The analysis of CD spectra with adapted algorithms using appropriate reference sets of protein spectra allows to extract the composition in term of secondary structural elements[42]. Then, following the CD spectrum as a function of time during the interaction with membranes can also give access to the kinetics of the structural changes which are intimately linked to the aggregation state. It has been shown that the presence of a membrane increases the amount of $\beta$-sheets in amyloidogenic proteins $[7,18,43]$, and favours fibrils formation. Fourier Transform InfraRed (FTIR) and Raman spectroscopies are two other techniques routinely used by chemists to analyze the secondary structure of peptides or proteins (Figure 2C). In the presence of lipidic systems, corresponding changes in the spectra indicate $\alpha$-helix or $\beta$-sheet organization[44], as recently exemplified with islet amyloid polypeptide in the presence of lipids [29,45].

The most used technique to extract aggregation kinetics is undeniably the measurement of Thioflavin $\mathrm{T}$ (ThT) fluorescence as a function of time (Figure 2C) [43]. ThT is a benzothiazole fluorescent dye whose fluorescence is enhanced upon binding to $\beta$-sheet rich amyloid aggregates. Typical ThT fluorescence aggregation curves have a sigmoidal shape from which the lag time and the time at half completion of the aggregation process can be estimated. These investigations allowed to show that membrane usually catalyse aggregation for example. Used together, $\mathrm{CD}$ and ThT fluorescence assays allow to connect the presence of aggregates to their secondary structure. They are often enriched by Transmission Electron Microscopy (TEM) which allows a monitoring of the morphology of the aggregates [43]. Nevertheless, these techniques are not well-suited for distinguishing between phenomena happening at the interface and in the bulk. Very recently, Gulacsy and coll.[46] proposed a new tool for monitoring the formation of toxic $A \beta$ species through high resolution microscopy based on the edge excitation shift phenomenon (EES). They were able to detect the formation of subvisible $(<1 \mu \mathrm{m}) \mathrm{A} \beta$ aggregates in a site-specific manner near the neuron membrane (Figure $2 \mathrm{C}$ ). The EES phenomenon corresponds to a change in the peak maximum of the fluorescence emission spectra upon increasing the excitation wavelength. The EES usually depends on the fluorophore environment (i.e. dipole moment), and it is influenced by the aggregation state of the protein: it appears in the early stage of aggregation and saturates for aggregates approaching $1 \mu \mathrm{m}$ size. Using a confocal microscope with spectral detection, they could measure the emission spectra at different laser wavelengths during the scanning of all the subcellular regions, thus mapping the EES in the whole cell.

\subsection{Probing structural and dynamical changes on membrane}

As a consequence of interaction with proteins, lipid membranes can be modified in their internal structure and even heavily damaged by the presence of protein aggregates. For example, amyloidogenic proteins are known to induce nonspecific ion channels in lipid membranes [47]. Indeed, protein aggregates which insert in the membrane could be the cause of pore formation which could reduce membrane potential and alter $\mathrm{Ca}^{2+}$ regulation, common 
characteristics of neurodegenerative diseases. In particular, mitochondria membranes were proved to be affected by the presence of $A \beta, \alpha$-synuclein and Tau oligomers[48,49].

In order to characterize these effects, techniques of choice are conductimetry, AFM and leakage experiments (Figure 2C). Bilayer electrical recording allows the identification of single channels as it measures induced current flow and single channel conductance across a freestanding phospholipid membrane. Besides, selectivity between positively and negatively charged ions can be inferred by current-voltage ramp experiments under asymmetric conditions on the sides of the membrane. From the conductance values, the pore size can be estimated by assuming a cylindrical shape[48]. These measurements are quite tricky and conductance values can spam from few tenths of $\mathrm{pS}$ (in the case of Tau protein) to a thousand $\mathrm{pS}$ (in the case of A $\beta$ )[50,51]. These measurements also allow following the time evolution of current traces, then identifying the opening times of the pores and indirectly the time necessary for protein insertion in the membrane.

Tapping mode AFM allows recognizing the presence of pore-like structures on lipid bilayers formed by four or five subunits arranged in a circular way[50]. These structures have quite small protrusion height $(1.5-1.8 \mathrm{~nm})$ so that they can be distinguished from annular protofibrils $(3.6 \pm 0.77 \mathrm{~nm})$. AFM can also be used in contact mode for force spectroscopy measurements and inform on the mechanical properties of the model membrane[52]. In this case, force versus distance curves are registered approaching the AFM cantilever to the membrane and allow determining the breakthrough force for Supported Lipid Bilayer (SLB) directly linked to lipid order and packing in the membrane.

Membrane permeabilisation is often connected with the formation of ion-conducting pores. For this purpose, leakage experiments are performed on model membranes, i.e. liposomes. A fluorescent dye whose signal depends on its concentration (i.e. fluorescein or calcein fluorescence is quenched when they are highly concentrated inside the liposomes) or on the presence of specific ions $\left(\mathrm{Ca}^{2+}\right.$ binding to Oregon green induce an increase in its fluorescence signal) is encapsulated inside the liposomes[48,53]. The extent of the increase in fluorescence signal due to dye exit outside liposomes allows evaluating membrane permeabilisation.

Both the insertion of protein into the membrane and its binding onto the surface can induce structural changes and affect the bilayer properties in terms of organization and dynamics. These effects can be evaluated through fluorescence polarization measurements of a probe included in the membrane (usually diphenylhexatriene, DPH, or its phospholipid derivatives) or by Raman spectroscopy. Both of these techniques inform on the degree of molecular packing (order) in the apolar regions of the membrane of Large Unilamellar Vesicles (LUVs): both the steady-state fluorescence anisotropy of DPH and the ratio between the 2880 $\mathrm{cm}^{-1}$ antisymmetric and $2850 \mathrm{~cm}^{-1}$ symmetric $\mathrm{CH}_{2}$ stretching vibration lines increases with the order parameter[54,55]. They are well-established techniques, easily accessible in physicalchemistry laboratories, but they proved some limitations. The steady-state fluorescence anisotropy of DPH can be influenced by the DPH fate which can be extracted from the membrane in the $A \beta$ oligomers[54]. Raman spectroscopy could not be sensitive enough to subtle changes in the lipid mobility not necessarily connected to a phase change. The use of neutron scattering techniques, such as Neutron Spin Echo (NSE) or Quasi-elastic neutron 
Scattering (QENS) can avoid the artefacts due to the use of a probe. NSE experiments carried out at length scale corresponding to the thickness of the lipid bilayer can inform on its dynamical properties as they measure the bilayer bending elasticity (Figure 2C) [56]. QENS can give access to diffusion coefficients relative to two different kinds of lipid motion, i.e. the lateral motion of the lipid molecules within monolayer and internal motion of lipid molecules[57,58]. Also, techniques adapted to supported lipid bilayer (SLB) have been developed, like Fluorescence Recovery After Photobleaching (FRAP), which allows to measure the 2D diffusion coefficient of labelled lipids directly on the membrane (Figure 2C) [20]. FRAP experiments have shown, for example, that higher $A \beta$ concentrations led to a decrease of membrane fluidity related to strong $A \beta$ peptide-membrane interactions. In this way, the measured effects are undoubtedly located in the bilayer: it is a local measurement so it needs a number of statistically valid measurements in order to be representative, but it can infer on possible inhomogeneities.

The above described techniques do not inform on the localization of the protein. Other techniques, based on scattering, reflectivity or diffraction, must be used to have insight in the structural characteristics of the membranes both in the form of SUV or LUV and SLB. For studies in solution, small and wide angle scattering (both neutron[57] and X-ray[59]) can assess the properties of the bilayers in terms of its thickness and lipid-lipid distance. If multilamellar vesicles are used[60], the decrease in the degree of correlation between the bilayers can also inform on the effect of possible insertion of proteins. Very small or no changes in the structural parameters can exclude the insertion of proteins in the bilayers[57], but usually more than one experimental technique is necessary in order to decide and structural studies of monolayers or bilayers must be carried out.

Wide angle X-ray diffraction on hydrated multilamellar bilayers gives a 2D intensity map from which information on the crystallographic parameters of the lipid tails (i.e. lateral distance between lipids and bilayer width) can be derived, so as to verify the insertion of proteins in the membrane[61]. Besides, the difference of the electron density profiles with and without the protein can be compared with calculated electron density profiles according to models. In this way, it is possible to extract the position and orientation of the protein in the bilayer[62]. Analog experiments using neutrons can be performed and specific deuteration of the peptide could allow its localization[63].

Reflectivity (neutron[64] and X-ray[18,65]) in situ measurements on monolayers at the water/air interface or supported lipid bilayers provide information of the composition and thickness of the membranes along the direction perpendicular to the bilayer with a sub-nm resolution. In order to probe lateral structures at the nanometer scale, grazing incidence small angle scattering can be used[65]. The above mentioned techniques are very powerful, but most of the time, special facilities are needed where beamtime can be allocated through proposals. Thus, fluorescence imaging techniques can be an interesting alternative as it is available in the laboratory. Phenomena such as remodelling of the membrane (i.e. formation of buds and tubules) can be detected and characterized by epifluorescence microscopy[20]. Very recently, total internal reflection fluorescence (TIRF) microscope equipped with good CCD camera was developed and was able to catch the kinetics of protein aggregation at the membrane surface 
(Figure 2C) and using super resolution microscopy the details of $\mathrm{A} \beta$ aggregates could be resolved down to tenths of $\mathrm{nm}[14]$.

\section{Discussion - Concluding remarks}

Multi-technique-based experiments are often required for studying protein-lipid interaction, as exemplified by Kadavath and coll.[36] and Ait-Bouziad and coll.[7]. Among the analytical techniques commonly used (compared in Table 1), some of them are easily accessible, such as CD, FTIR, or microscopy, and some others need to work with labelled protein or lipid (FRET, FRAP, FCS), which implies a step of chemical reaction with fluorescent dye prior analysis. The physical and chemical properties of protein or lipid may be affected by the presence of the fluorescent label. Other techniques are even hardly accessible as they require national infrastructures (neutron scattering).

The use of at least either NMR or MS (or both) is, most of the time, mandatory to collect molecular information on the interaction. MS is much more sensitive than NMR and thus allows working under physiological relevant conditions, at very low protein and lipid concentrations. Moreover, MS is not based on average measurements in time, contrary to NMR, which is a very strong asset when dealing with interacting molecules. This information can be completed with other thermodynamic parameters brought by other complementary techniques (e.g. ITC).

In order to go beyond the molecular and very precise localization standpoint, other techniques are needed and bring valuable additional information. These techniques are wellknown from the physical chemistry field but have to be adapted to the challenge of disease understanding. For instance, fluorescence microscopy or the different scattering techniques presented here (light, neutron or X-ray) enable to observe the consequences of the protein-lipid interaction from a larger scale than the molecules, evidencing changes in size, environment and can be used to probe the phenomena happening at the membrane-water interphase.

Moreover, several techniques, already well established, are constantly evolving and it is now possible to obtain several types of information with the same technique. MS is once again a good example, since it is possible to obtain the localization of the interaction and its consequences regarding protein aggregation, using cross-coupling experiments and IMS-MS, respectively. The same applies to fluorescence microcopy, which is increasingly used to identify precise interactions through probe lifetime, diffusion coefficients or monitoring edge excitation shift, by using high resolution confocal imaging for example. When equipped with high speed camera, time-lapse imaging is also possible and the kinetic aspects of the interactions can be tackled. New microscopy concepts have been also developed which allow super resolution, much better than the diffraction limit, and then precise localization on the membrane surface is possible. Other examples are evolutions of Raman spectroscopy such as Surface Enhanced Raman Spectroscopy to amplify signal intensities and THz spectroscopy for which recent technical developments have led to more easily accessible set-ups[66]. However, all these techniques are actually variations of a generic technique, such as MS or fluorescence microscopy, which cannot be performed simultaneously on the same spectrometer or microscope. Thus, understanding protein-lipid interaction in Alzheimer's disease effectively requires multi-technique-based analytical strategies. And it should be expected that techniques 
so far limited to simple molecular systems like pure proteins evolve towards more complex ones joining together proteins and lipids or membrane extracts.

\section{References}

1. Christie, W.W.; Han, X. Chapter 1 - Lipids: their structures and occurrence. In Lipid Analysis (Fourth Edition), Christie, W.W., Han, X., Eds. Woodhead Publishing: 2012; pp. 3-19.

2. Chew, H.; Solomon, V.A.; Fonteh, A.N. Involvement of Lipids in Alzheimer's Disease Pathology and Potential Therapies. Front Physiol 2020, 11, 598.

3. Hentschel, A.; Zahedi, R.P.; Ahrends, R. Protein lipid modifications--More than just a greasy ballast. Proteomics 2016, 16, 759-782.

4. Goedert, M.; Spillantini, M.G. A century of Alzheimer's disease. Science 2006, 314, 777-781.

5. Hardy, J.; Selkoe, D.J. The amyloid hypothesis of Alzheimer's disease: progress and problems on the road to therapeutics. Science 2002, 297, 353-356.

6. Spillantini, M.G.; Goedert, M. Tau pathology and neurodegeneration. Lancet Neurol 2013, 12, 609-622.

7. $\quad$ Ait-Bouziad, N.; Lv, G.; Mahul-Mellier, A.-L.; Xiao, S.; Zorludemir, G.; Eliezer, D.; Walz, T.; Lashuel, H.A. Discovery and characterization of stable and toxic Tau/phospholipid oligomeric complexes. Nature Communications 2017, 8, 1678.

8. Niu, Z.; Zhang, Z.; Zhao, W.; Yang, J. Interactions between amyloid $\beta$ peptide and lipid membranes. Biochimica et Biophysica Acta (BBA) - Biomembranes 2018, 1860, 1663 1669.

9. Rangachari, V.; Dean, D.N.; Rana, P.; Vaidya, A.; Ghosh, P. Cause and consequence of A $\beta$ - Lipid interactions in Alzheimer disease pathogenesis. Biochimica et Biophysica Acta (BBA) - Biomembranes 2018, 1860, 1652-1662.

10. Chang, C.C.; Edwald, E.; Veatch, S.; Steel, D.G.; Gafni, A. Interactions of amyloidbeta peptides on lipid bilayer studied by single molecule imaging and tracking. Biochim Biophys Acta Biomembr 2018.

11. Xing, Y.; Pilkington, E.H.; Wang, M.; Nowell, C.J.; Kakinen, A.; Sun, Y.; Wang, B.; Davis, T.P.; Ding, F.; Ke, P.C. Lysophosphatidylcholine modulates the aggregation of human islet amyloid polypeptide. Phys Chem Chem Phys 2017, 19, 30627-30635.

12. Yeagle, P.L. Chapter 6 - Laboratory Membrane Systems. In The Membranes of Cells (Third Edition), Yeagle, P.L., Ed. Academic Press: Boston, 2016; pp. 95-114.

13. Ishima, R.; Torchia, D.A. Protein dynamics from NMR. Nat Struct Biol 2000, 7, 740743.

14. Tahirbegi, B.; Magness, A.J.; Piersimoni, M.E.; Knopfel, T.; Willison, K.R.; Klug, D.R.; Ying, L. A Novel Abeta40 Assembly at Physiological Concentration. Sci Rep $2020,10,9477$.

15. Shezad, K.; Zhang, K.; Hussain, M.; Dong, H.; He, C.; Gong, X.; Xie, X.; Zhu, J.; Shen, L. Surface Roughness Modulates Diffusion and Fibrillation of Amyloid-beta Peptide. Langmuir 2016, 32, 8238-8244.

16. Mari, S.A.; Wegmann, S.; Tepper, K.; Hyman, B.T.; Mandelkow, E.-M.; Mandelkow, E.; Müller, D.J. Reversible Cation-Selective Attachment and Self-Assembly of Human Tau on Supported Brain Lipid Membranes. Nano Letters 2018, 18, 3271-3281.

17. Jones, E.M.; Dubey, M.; Camp, P.J.; Vernon, B.C.; Biernat, J.; Mandelkow, E.; Majewski, J.; Chi, E.Y. Interaction of Tau Protein with Model Lipid Membranes 
Induces Tau Structural Compaction and Membrane Disruption. Biochemistry 2012, 51, 2539-2550.

18. Fanni, A.M.; Vander Zanden, C.M.; Majewska, P.V.; Majewski, J.; Chi, E.Y. Membrane-mediated fibrillation and toxicity of the tau hexapeptide PHF6. Journal of Biological Chemistry 2019.

19. Nielsen, S.B.; Otzen, D.E. Quartz Crystal Microbalances as Tools for Probing ProteinMembrane Interactions. Methods Mol Biol 2019, 2003, 31-52.

20. Meker, S.; Chin, H.; Sut, T.N.; Cho, N.J. Amyloid-beta Peptide Triggers Membrane Remodeling in Supported Lipid Bilayers Depending on Their Hydrophobic Thickness. Langmuir 2018, 34, 9548-9560.

21. Dicke, S.S.; Tatge, L.; Engen, P.E.; Culp, M.; Masterson, L.R. Isothermal titration calorimetry and vesicle leakage assays highlight the differential behaviors of tau repeat segments upon interaction with anionic lipid membranes. Biochemical and Biophysical Research Communications 2017, 493, 1504-1509.

22. Terakawa, M.S.; Lin, Y.; Kinoshita, M.; Kanemura, S.; Itoh, D.; Sugiki, T.; Okumura, M.; Ramamoorthy, A.; Lee, Y.-H. Impact of membrane curvature on amyloid aggregation. Biochimica et Biophysica Acta (BBA) - Biomembranes 2018, 1860, 17411764.

23. Terakawa, M.S.; Yagi, H.; Adachi, M.; Lee, Y.H.; Goto, Y. Small liposomes accelerate the fibrillation of amyloid beta (1-40). J Biol Chem 2015, 290, 815-826.

24. Jahnke, N.; Krylova, O.O.; Hoomann, T.; Vargas, C.; Fiedler, S.; Pohl, P.; Keller, S. Real-time monitoring of membrane-protein reconstitution by isothermal titration calorimetry. Anal Chem 2014, 86, 920-927.

25. Laganowsky, A.; Reading, E.; Allison, T.M.; Ulmschneider, M.B.; Degiacomi, M.T.; Baldwin, A.J.; Robinson, C.V. Membrane proteins bind lipids selectively to modulate their structure and function. Nature 2014, 510, 172-175.

26. Yano, Y.; Takeno, A.; Matsuzaki, K. Trace amounts of pyroglutaminated A $\beta-(3-42)$ enhance aggregation of $\mathrm{A} \beta-(1-42)$ on neuronal membranes at physiological concentrations: FCS analysis of cell surface. Biochimica et Biophysica Acta (BBA) Biomembranes 2018, 1860, 1603-1608.

27. Elbaum-Garfinkle, S.; Ramlall, T.; Rhoades, E. The Role of the Lipid Bilayer in Tau Aggregation. Biophysical Journal 2010, 98, 2722-2730.

28. Qiu, L.; Lewis, A.; Como, J.; Vaughn, M.W.; Huang, J.; Somerharju, P.; Virtanen, J.; Cheng, K.H. Cholesterol modulates the interaction of beta-amyloid peptide with lipid bilayers. Biophysical Journal 2009, 96, 4299-4307.

29. Rawat, A.; Maity, B.K.; Chandra, B.; Maiti, S. Aggregation-induced conformation changes dictate islet amyloid polypeptide (IAPP) membrane affinity. Biochimica et Biophysica Acta (BBA) - Biomembranes 2018, 1860, 1734-1740.

30. Vandelinder, V.; Ferreon, A.C.; Gambin, Y.; Deniz, A.A.; Groisman, A. Highresolution temperature-concentration diagram of alpha-synuclein conformation obtained from a single Forster resonance energy transfer image in a microfluidic device. Anal Chem 2009, 81, 6929-6935.

31. Georgieva, Elka R.; Xiao, S.; Borbat, Peter P.; Freed, Jack H.; Eliezer, D. Tau Binds to Lipid Membrane Surfaces via Short Amphipathic Helices Located in Its MicrotubuleBinding Repeats. Biophysical Journal 2014, 107, 1441-1452.

32. Singh, J.; Peric, M. Interaction of the beta amyloid - Abeta(25-35) - peptide with zwitterionic and negatively charged vesicles with and without cholesterol. Chem Phys Lipids 2018, 216, 39-47. 
33. Österlund, N.; Luo, J.; Wärmländer, S.K.T.S.; Gräslund, A. Membrane-mimetic systems for biophysical studies of the amyloid- $\beta$ peptide. Biochimica et Biophysica Acta (BBA) - Proteins and Proteomics 2019, 1867, 492-501.

34. Barré, P.; Eliezer, D. Folding of the Repeat Domain of Tau Upon Binding to Lipid Surfaces. Journal of Molecular Biology 2006, 362, 312-326.

35. Barré, P.; Eliezer, D. Structural transitions in tau k18 on micelle binding suggest a hierarchy in the efficacy of individual microtubule-binding repeats in filament nucleation. Protein Science 2013, 22, 1037-1048.

36. Kadavath, H.; Hofele, R.V.; Biernat, J.; Kumar, S.; Tepper, K.; Urlaub, H.; Mandelkow, E.; Zweckstetter, M. Tau stabilizes microtubules by binding at the interface between tubulin heterodimers. Proceedings of the National Academy of Sciences 2015, 112, 7501-7506.

37. Liu, Y.; Cong, X.; Liu, W.; Laganowsky, A. Characterization of Membrane ProteinLipid Interactions by Mass Spectrometry Ion Mobility Mass Spectrometry. Journal of The American Society for Mass Spectrometry 2017, 28, 579-586.

38. Allison, T.M.; Bechara, C. Structural mass spectrometry comes of age: new insight into protein structure, function and interactions. Biochemical Society Transactions 2019, 47, 317-327.

39. Frame, N.M.; Kumanan, M.; Wales, T.E.; Bandara, A.; Fandrich, M.; Straub, J.E.; Engen, J.R.; Gursky, O. Structural Basis for Lipid Binding and Function by an Evolutionarily Conserved Protein, Serum Amyloid A. Journal of Molecular Biology 2020, 432, 1978-1995.

40. Cecchi, C.; Stefani, M. The amyloid-cell membrane system. The interplay between the biophysical features of oligomers/fibrils and cell membrane defines amyloid toxicity. Biophys Chem 2013, 182, 30-43.

41. Greenfield, N.J. Using circular dichroism spectra to estimate protein secondary structure. Nat Protoc 2006, 1, 2876-2890.

42. Micsonai, A.; Wien, F.; Kernya, L.; Lee, Y.H.; Goto, Y.; Refregiers, M.; Kardos, J. Accurate secondary structure prediction and fold recognition for circular dichroism spectroscopy. Proc Natl Acad Sci U S A 2015, 112, E3095-3103.

43. Korshavn, K.J.; Satriano, C.; Lin, Y.; Zhang, R.; Dulchavsky, M.; Bhunia, A.; Ivanova, M.I.; Lee, Y.H.; La Rosa, C.; Lim, M.H., et al. Reduced Lipid Bilayer Thickness Regulates the Aggregation and Cytotoxicity of Amyloid-beta. J Biol Chem 2017, 292, 4638-4650.

44. Bharadwaj, P.; Solomon, T.; Malajczuk, C.J.; Mancera, R.L.; Howard, M.; Arrigan, D.W.M.; Newsholme, P.; Martins, R.N. Role of the cell membrane interface in modulating production and uptake of Alzheimer's beta amyloid protein. Biochimica et Biophysica Acta (BBA) - Biomembranes 2018, 1860, 1639-1651.

45. Rawat, A.; Langen, R.; Varkey, J. Membranes as modulators of amyloid protein misfolding and target of toxicity. Biochimica et Biophysica Acta (BBA) Biomembranes 2018, 1860, 1863-1875.

46. Gulacsy, C.E.; Meade, R.; Catici, D.A.M.; Soeller, C.; Pantos, G.D.; Jones, D.D.; Alibhai, D.; Jepson, M.; Valev, V.K.; Mason, J.M., et al. Excitation-Energy-Dependent Molecular Beacon Detects Early Stage Neurotoxic Abeta Aggregates in the Presence of Cortical Neurons. ACS Chem Neurosci 2019, 10, 1240-1250.

47. Kagan, B.L. Membrane pores in the pathogenesis of neurodegenerative disease. Prog Mol Biol Transl Sci 2012, 107, 295-325.

48. Camilleri, A.; Ghio, S.; Caruana, M.; Weckbecker, D.; Schmidt, F.; Kamp, F.; Leonov, A.; Ryazanov, S.; Griesinger, C.; Giese, A., et al. Tau-induced mitochondrial 
membrane perturbation is dependent upon cardiolipin. Biochim Biophys Acta Biomembr 2020, 1862, 183064.

49. Angelova, P.R.; Abramov, A.Y. Alpha-synuclein and beta-amyloid - different targets, same players: calcium, free radicals and mitochondria in the mechanism of neurodegeneration. Biochemical and Biophysical Research Communications 2017, 483, 1110-1115.

50. Patel, N.; Ramachandran, S.; Azimov, R.; Kagan, B.L.; Lal, R. Ion Channel Formation by Tau Protein: Implications for Alzheimer's Disease and Tauopathies. Biochemistry 2015, 54, 7320-7325.

51. Bode, D.C.; Baker, M.D.; Viles, J.H. Ion Channel Formation by Amyloid-beta42 Oligomers but Not Amyloid-beta40 in Cellular Membranes. J Biol Chem 2017, 292, 1404-1413.

52. Canale, C.; Seghezza, S.; Vilasi, S.; Carrotta, R.; Bulone, D.; Diaspro, A.; San Biagio, P.L.; Dante, S. Different effects of Alzheimer's peptide Abeta(1-40) oligomers and fibrils on supported lipid membranes. Biophys Chem 2013, 182, 23-29.

53. Tatulian, S.A.; Kandel, N. Membrane Pore Formation by Peptides Studied by Fluorescence Techniques. Methods Mol Biol 2019, 2003, 449-464.

54. Suzuki, M.; Miura, T. Effect of amyloid beta-peptide on the fluidity of phosphatidylcholine membranes: Uses and limitations of diphenylhexatriene fluorescence anisotropy. Biochim Biophys Acta 2015, 1848, 753-759.

55. Dmitriev, A.A.; Surovtsev, N.V. Temperature-Dependent Hydrocarbon Chain Disorder in Phosphatidylcholine Bilayers Studied by Raman Spectroscopy. J Phys Chem B 2015, 119, 15613-15622.

56. Ricci, C.; Maccarini, M.; Falus, P.; Librizzi, F.; Mangione, M.R.; Moran, O.; Ortore, M.G.; Schweins, R.; Vilasi, S.; Carrotta, R. Amyloid beta-Peptide Interaction with Membranes: Can Chaperones Change the Fate? J Phys Chem B 2019, 123, 631-638.

57. Rai, D.K.; Sharma, V.K.; Anunciado, D.; O'Neill, H.; Mamontov, E.; Urban, V.; Heller, W.T.; Qian, S. Neutron Scattering Studies of the Interplay of Amyloid beta Peptide(140) and An Anionic Lipid 1,2-dimyristoyl-sn-glycero-3-phosphoglycerol. Sci Rep 2016, 6, 30983.

58. Fichou, Y.; Schiro, G.; Gallat, F.X.; Laguri, C.; Moulin, M.; Combet, J.; Zamponi, M.; Hartlein, M.; Picart, C.; Mossou, E., et al. Hydration water mobility is enhanced around tau amyloid fibers. Proc Natl Acad Sci U S A 2015, 112, 6365-6370.

59. Colombo, L.; Gamba, A.; Cantu, L.; Salmona, M.; Tagliavini, F.; Rondelli, V.; Del Favero, E.; Brocca, P. Pathogenic Abeta A2V versus protective Abeta A2T mutation: Early stage aggregation and membrane interaction. Biophys Chem 2017, 229, 11-18.

60. Hoernke, M.; Tassler, S.; Koksch, B.; Brezesinski, G. Membrane binding of peptide models for early stages of amyloid formation: Lipid packing counts more than charge. Chem Phys Lipids 2016, 198, 28-38.

61. Ahmed, R.; Akcan, M.; Khondker, A.; Rheinstadter, M.C.; Bozelli, J.C., Jr.; Epand, R.M.; Huynh, V.; Wylie, R.G.; Boulton, S.; Huang, J., et al. Atomic resolution map of the soluble amyloid beta assembly toxic surfaces. Chem Sci 2019, 10, 6072-6082.

62. Barrett, M.A.; Alsop, R.J.; Hauss, T.; Rheinstadter, M.C. The Position of Abeta22-40 and Abeta1-42 in Anionic Lipid Membranes Containing Cholesterol. Membranes (Basel) 2015, 5, 824-843.

63. Dante, S.; Hauss, T.; Brandt, A.; Dencher, N.A. Membrane fusogenic activity of the Alzheimer's peptide A beta(1-42) demonstrated by small-angle neutron scattering. Journal of Molecular Biology 2008, 376, 393-404.

64. Martel, A.; Antony, L.; Gerelli, Y.; Porcar, L.; Fluitt, A.; Hoffmann, K.; Kiesel, I.; Vivaudou, M.; Fragneto, G.; de Pablo, J.J. Membrane Permeation versus 
Amyloidogenicity: A Multitechnique Study of Islet Amyloid Polypeptide Interaction with Model Membranes. J Am Chem Soc 2017, 139, 137-148.

65. Vander Zanden, C.M.; Wampler, L.; Bowers, I.; Watkins, E.B.; Majewski, J.; Chi, E.Y. Fibrillar and Nonfibrillar Amyloid Beta Structures Drive Two Modes of MembraneMediated Toxicity. Langmuir 2019, 35, 16024-16036.

66. Heo, C.; Ha, T.; You, C.; Huynh, T.; Lim, H.; Kim, J.; Kesama, M.R.; Lee, J.; Kim, T.T.; Lee, Y.H. Identifying Fibrillization State of Abeta Protein via Near-Field THz Conductance Measurement. ACS Nano 2020, 14, 6548-6558. 


\section{Figure and table captions}

Figure 1: schematic depiction of some protein-lipid interaction in relation with Alzheimer's disease. $A \beta$ is generated from the transmembrane APP protein, after cleavage by $\beta$ - and $\gamma$-secretases. Interaction with membrane lipids proceeds via insertion or binding, leading to ion channel-like structures (and membrane permeabilization) or to aggregation and formation of amyloid fibrils, respectively. Tau interaction with microtubules might disrupt upon abnormal phosphorylation, leading to microtubule destructuration and Tau releasing. This latter can interact with membrane-phospholipid to generate Tau-phospholipids complexes. A schematic representation of the Tau domains is also given, along with $A \beta$ sequence and chemical formulae of main classes of lipids. APP $=$ Amyloid Protein Precursor, $A \beta=$ beta-amyloid peptide, Tau = Microtubule Associated Protein - Tubuline Associated Unit (MAP-Tau), R1-R4 = repeat regions of Tau, PHF6 and PHF6* $=$ hexapeptides involved in Paired Helical Filament assembly, $\beta$ - and $\gamma$-sec $=\beta$ - and $\gamma$-secretases.

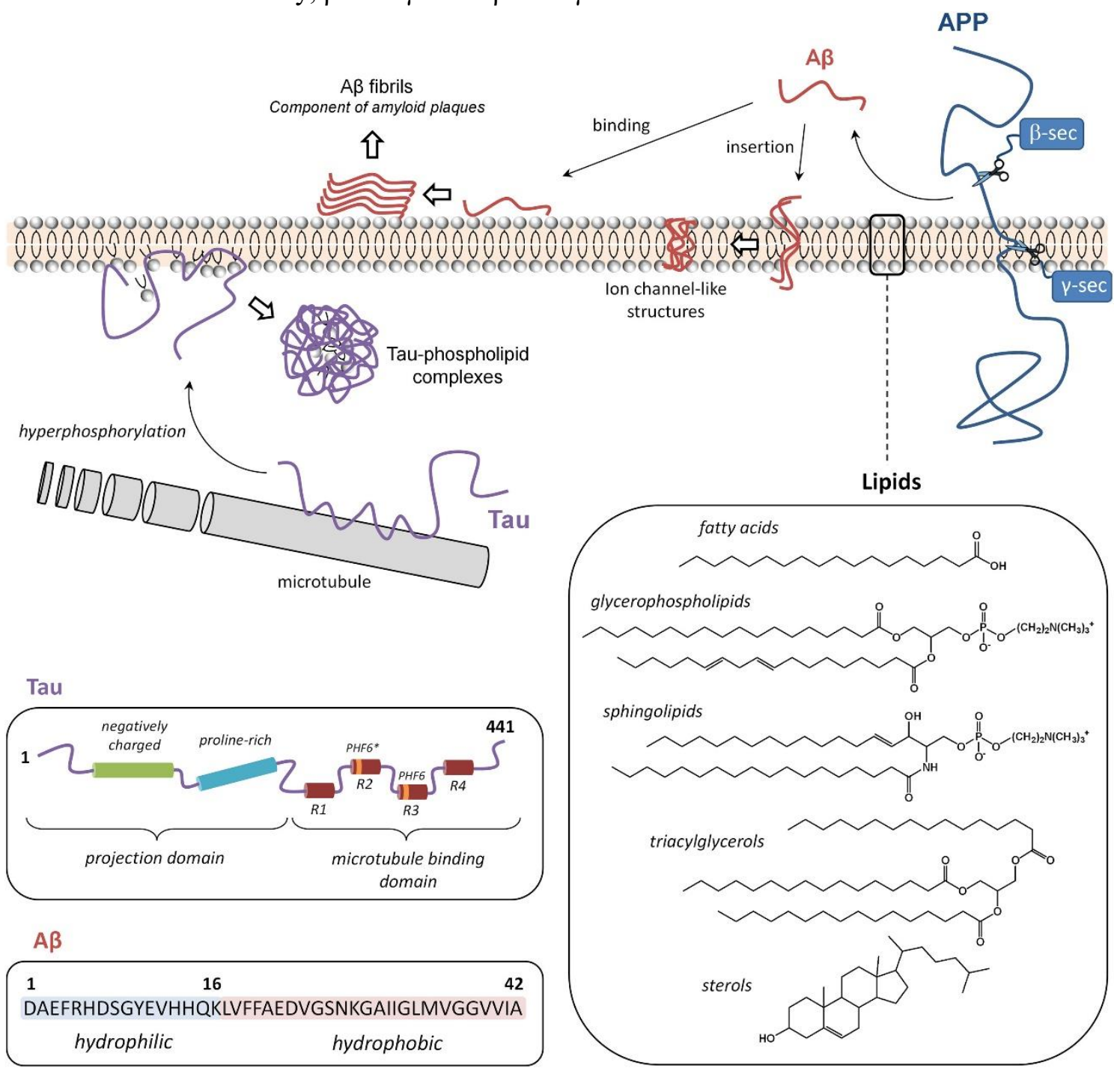

Figure 2: information about protein-lipid interaction given by each analytical technique. Analytical techniques are sorted according to the class of information they can provide: A) existence, B) localization, and C) consequences of the protein-lipid interaction. See the text for details. AFM = Atomic Force Microscopy, $\mathrm{CD}=$ Circular Dichroism, EES $=$ Edge Excitation Shift, FRAP = Fluorescence Recovery After Photobleaching, FRET = Förster (or fluorescence) Resonance Energy 
Transfer, FTIR $=$ Fourier Transform InfraRed, HDX-MS $=$ Hydrogen-Deuterium eXchange - Mass Spectrometry, IM-MS = Ion Mobility - Mass Spectrometry, ITC = IsoThermal Calorimetry, NMR = Nuclear Magnetic Resonance, QCM-D = Quartz Crystal Microbalance with Dispersion monitoring, ThT $=$ Thioflavin T; TIRF $=$ Total Internal Reflection Fluorescence .

A)
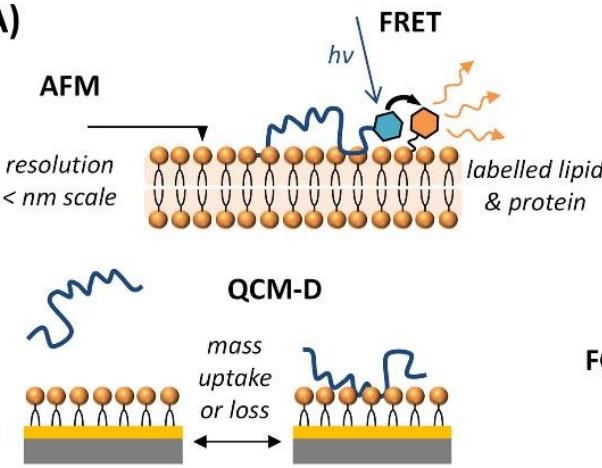

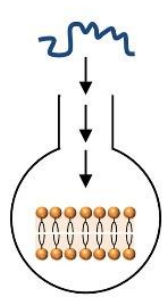

ITC

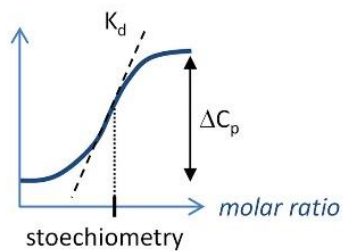

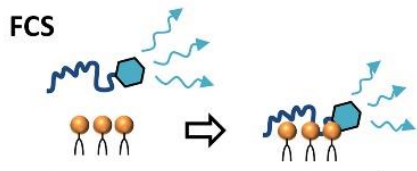

change in Brownian motion $=f($ size $)$

B)

MS
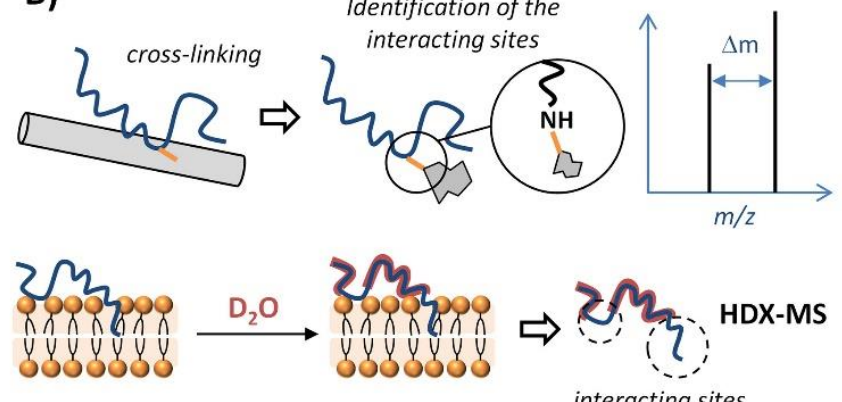

NMR

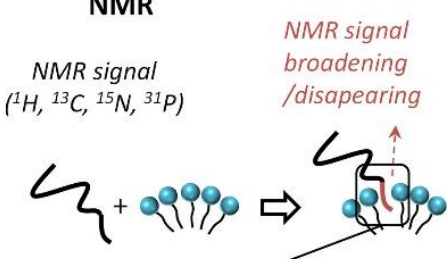

$\sim_{\text {GYEVHHQKLVF }}$

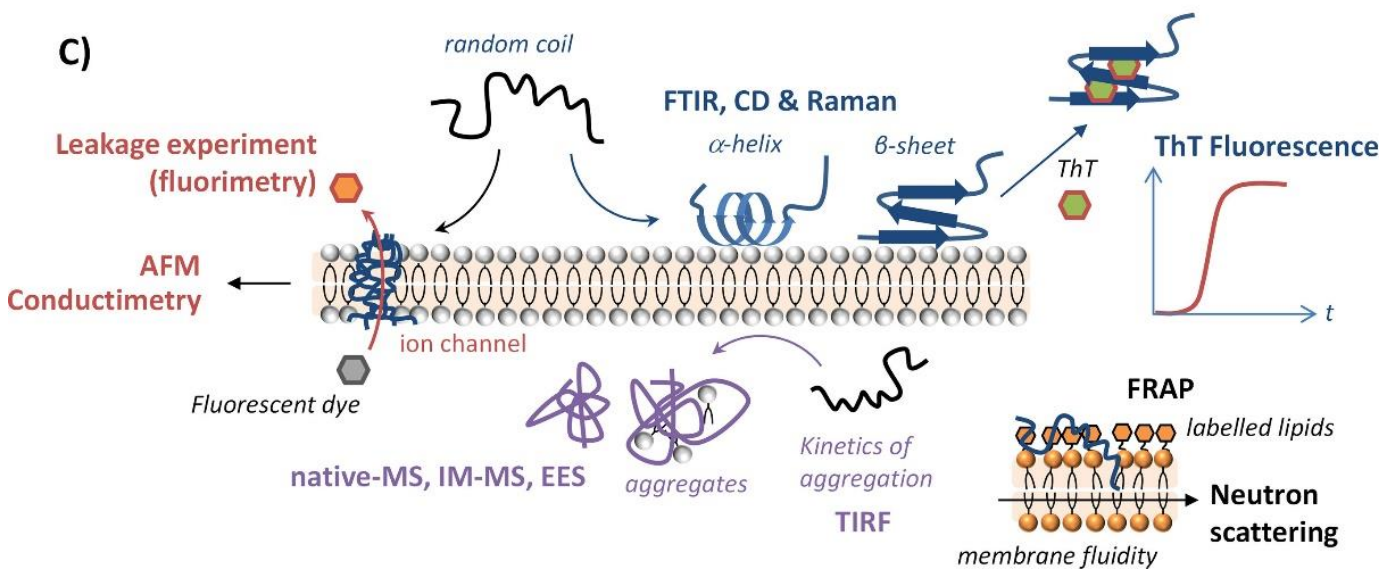


Table 1: characteristics of analytical techniques used for studying protein-lipid interaction.

\begin{tabular}{|c|c|c|c|c|}
\hline $\begin{array}{c}\text { Analytical } \\
\text { technique }\end{array}$ & Principle & $\begin{array}{c}\text { Extracted } \\
\text { information }\end{array}$ & Assets, drawbacks & Ref \\
\hline $\begin{array}{l}\text { Electron } \\
\text { microscopy }\end{array}$ & $\begin{array}{l}\text { Imaging with } \\
\text { electron beam }\end{array}$ & $\begin{array}{l}\text { Lipid organization } \\
\text { changes upon } \\
\text { protein interaction }\end{array}$ & $\begin{array}{l}\text { nm resolution, TEM easily accessible, } \\
\text { possible need of contrast agent, TEM } \\
\text { implies drying of the sample. Cryo- } \\
\text { TEM less easy to perform }\end{array}$ & {$[7,43]$} \\
\hline $\begin{array}{l}\text { Atomic force } \\
\text { microscopy (AFM) }\end{array}$ & $\begin{array}{l}\text { Surface scanning } \\
\text { with a modified } \\
\text { cantilever }\end{array}$ & $\begin{array}{l}\text { Visualization of } \\
\text { pores and protein } \\
\text { aggregates on the } \\
\text { membrane surface. } \\
\text { Interaction energies } \\
\text { between the two } \\
\text { components }\end{array}$ & $\begin{array}{l}\text { Needs experts, quantification of } \\
\text { energies depends on the validity of the } \\
\text { model used, } \mathrm{nm} \text { resolution }\end{array}$ & $\begin{array}{l}{[13,15,5} \\
0,52]\end{array}$ \\
\hline $\begin{array}{l}\text { Fluorescence and } \\
\text { confocal } \\
\text { microscopy }\end{array}$ & $\begin{array}{l}\text { Imaging of } \\
\text { fluorescent probes }\end{array}$ & $\begin{array}{l}\text { Localization of the } \\
\text { probes, evidence of } \\
\text { aggregate formation } \\
\text { at the membrane } \\
\text { surface. }\end{array}$ & $\begin{array}{l}\text { Easily accessible, } \mu \mathrm{m} \text { resolution; need } \\
\text { for a fluorescent probe (need for protein } \\
\text { and lipid chemical modification). }\end{array}$ & {$[20]$} \\
\hline $\begin{array}{l}\text { Confocal } \\
\text { microscopy coupled } \\
\text { with Edge } \\
\text { Excitation Shift } \\
\text { (EES) detection) }\end{array}$ & $\begin{array}{l}\text { Monitoring the } \\
\text { change of peak } \\
\text { fluorescence by } \\
\text { changing the } \\
\text { excitation } \\
\text { wavelength }\end{array}$ & $\begin{array}{l}\text { Visualization of } \\
\text { early stage } \\
\text { aggregates }(<1 \mu \mathrm{m}) \\
\text { formed on } \\
\text { membranes }\end{array}$ & $\begin{array}{l}\text { use of fluorophores, need for protein } \\
\text { and lipid chemical modification, used } \\
\text { with confocal microscopy resolution } \\
\text { down to } 200 \mathrm{~nm}\end{array}$ & [46] \\
\hline $\begin{array}{l}\text { Total internal } \\
\text { reflection } \\
\text { fluorescence (TIRF) }\end{array}$ & $\begin{array}{l}\text { Generation of an } \\
\text { evanescent wave to } \\
\text { excite fluorophores } \\
\text { located in a 50-200 } \\
\text { nm thin region at the } \\
\text { glass/water } \\
\text { interphase }\end{array}$ & $\begin{array}{l}\text { Imaging of } \\
\text { assemblies at the } \\
\text { membrane surface }\end{array}$ & $\begin{array}{l}\text { Axial resolution below } 100 \mathrm{~nm} \text {, use of } \\
\text { fluorophores, need for protein and lipid } \\
\text { chemical modification }\end{array}$ & {$[14]$} \\
\hline Fluorimetry FRAP & $\begin{array}{l}\text { Photobleaching is } \\
\text { induced by strong } \\
\text { irradiation, } \\
\text { fluorescence } \\
\text { recovery is followed } \\
\text { as a function of time }\end{array}$ & $\begin{array}{l}\text { 2D diffusion } \\
\text { coefficients of } \\
\text { labelled lipids }\end{array}$ & $\begin{array}{l}\text { Use of fluorophores, need for protein } \\
\text { and lipid chemical modification }\end{array}$ & {$[20]$} \\
\hline $\begin{array}{l}\text { Fluorescence } \\
\text { correlation } \\
\text { spectroscopy (FCS) }\end{array}$ & $\begin{array}{l}\text { Brownian motion of } \\
\text { fluorescent systems } \\
\text { linked to their size }\end{array}$ & $\begin{array}{l}\text { Determination of } \\
\text { fluorescent } \\
\text { molecule dynamics, } \\
\text { different in case of } \\
\text { interaction }\end{array}$ & $\begin{array}{l}\text { Interaction visible through the change } \\
\text { in dynamics. Possible cross information } \\
\text { with the use of } 2 \text { different probes, } \\
\text { Extraction of information linked to } \\
\text { mathematical models whose validation } \\
\text { is difficult. Very difficult extraction in } \\
\text { case of mixtures. }\end{array}$ & $\begin{array}{l}{[14,26,2} \\
7]\end{array}$ \\
\hline ThT fluorescence & $\begin{array}{l}\text { Fluorescence of ThT } \\
\text { when inserting into } \\
\beta \text {-sheet structures } \\
\end{array}$ & $\begin{array}{l}\text { Kinetics of } \\
\text { peptide/protein } \\
\text { aggregation }\end{array}$ & Easily accessible, and easy to perform & [43] \\
\hline $\begin{array}{l}\text { Leakage } \\
\text { experiments } \\
\text { (fluorescence) }\end{array}$ & $\begin{array}{l}\text { Fluorescence change } \\
\text { for a dye exiting } \\
\text { liposomes }\end{array}$ & $\begin{array}{l}\text { Ion channel } \\
\text { formation in } \\
\text { liposomes; } \\
\text { membrane } \\
\text { permeabilisation }\end{array}$ & $\begin{array}{l}\text { Easy to set up, impossible to distinguish } \\
\text { between pore formation or membrane } \\
\text { defects }\end{array}$ & {$[48,53]$} \\
\hline $\begin{array}{l}\text { Fluorescence } \\
\text { polarization } \\
\text { measurements }\end{array}$ & $\begin{array}{l}\text { Fluorescence } \\
\text { measurements where } \\
\text { both the excitation } \\
\text { and emission light is } \\
\text { polarized }\end{array}$ & $\begin{array}{l}\text { Anisotropy } \\
\text { coefficient linked to } \\
\text { probe mobility in } \\
\text { the membrane }\end{array}$ & Easily accessible, and easy to perform & {$[54,55]$} \\
\hline
\end{tabular}




\begin{tabular}{|c|c|c|c|c|}
\hline $\begin{array}{l}\text { Förster Resonance } \\
\text { Energy Transfer } \\
\text { (FRET) }\end{array}$ & $\begin{array}{l}\text { Energy transfer } \\
\text { between } \\
\text { fluorophores }\end{array}$ & $\begin{array}{l}\text { Evidence of spatial } \\
\text { proximity between } \\
\text { fluorophores }\end{array}$ & $\begin{array}{l}\text { Easily accessible, easy to perform, need } \\
\text { for the presence of different } \\
\text { fluorophores constituting a FRET } \\
\text { couple }\end{array}$ & {$[28-30]$} \\
\hline Circular dichroism & $\begin{array}{l}\text { Change of } \\
\text { polarization linked } \\
\text { to chromophores } \\
\text { organization }\end{array}$ & $\begin{array}{l}\text { 3D conformation, } \\
\text { possible interaction } \\
\text { visible with induced } \\
\text { CD }\end{array}$ & $\begin{array}{l}\text { Easily accessible, short organization not } \\
\text { visible, chromophore needed, more } \\
\text { difficult to analyze in the case of } \\
\text { mixtures of different conformations. }\end{array}$ & {$[7,18,43]$} \\
\hline $\begin{array}{l}\text { Infrared and Raman } \\
\text { spectroscopy }\end{array}$ & $\begin{array}{l}\text { Absorption bands } \\
\text { position depends on } \\
\text { the environment }\end{array}$ & $\begin{array}{l}\text { Interacting moieties, } \\
\text { access to 3D } \\
\text { organization in } \\
\text { some cases }\end{array}$ & $\begin{array}{l}\text { Easily accessible, need of long 3D } \\
\text { organization, difficult to analyze in case } \\
\text { of mixtures of different conformations. }\end{array}$ & $\begin{array}{l}{[29,44,4} \\
5]\end{array}$ \\
\hline $\begin{array}{l}\text { Nuclear Magnetic } \\
\text { Resonance (NMR) }\end{array}$ & $\begin{array}{l}\text { Proton relaxation } \\
\text { sensitive to its } \\
\text { environment, } \\
\text { therefore to } \\
\text { interactions }\end{array}$ & $\begin{array}{l}\text { Interacting moieties, } \\
\text { access to } 3 \mathrm{D} \\
\text { organization in } \\
\text { some cases }\end{array}$ & $\begin{array}{l}\text { Easily accessible for the basic form, } \\
\text { richest information needs experts. }\end{array}$ & $\begin{array}{l}{[7,33-} \\
36]\end{array}$ \\
\hline Mass spectrometry & $\begin{array}{l}\text { Molecular and } \\
\text { supramolecular } \\
\text { structural analysis }\end{array}$ & $\begin{array}{l}\text { Interacting groups, } \\
\text { structural } \\
\text { characterization, } \\
\text { supramolecular } \\
\text { complexes }\end{array}$ & $\begin{array}{l}\text { Very sensitive, acute information on } \\
\text { interacting sites, difficult to perform, } \\
\text { needs experts }\end{array}$ & $\begin{array}{l}{[25,36-} \\
38]\end{array}$ \\
\hline $\begin{array}{l}\text { Quartz crystal } \\
\text { microbalance } \\
\text { (QCM) }\end{array}$ & $\begin{array}{l}\text { Piezoelectric } \\
\text { response of gold } \\
\text { crystal depending on } \\
\text { adsorbed molecules }\end{array}$ & $\begin{array}{l}\text { Strength and kinetic } \\
\text { of interaction }\end{array}$ & $\begin{array}{l}\text { Reversible interaction to play with } \\
\text { thanks to washing steps } \\
\text { Need of chemical groups that can be } \\
\text { linked to gold. } \\
\text { No indication on which groups interact } \\
\text { together }\end{array}$ & [19] \\
\hline $\begin{array}{l}\text { Langmuir films } \\
\text { isotherms }\end{array}$ & $\begin{array}{l}\text { Interactions between } \\
\text { lipids and protein } \\
\text { seen through } \\
\text { modification of the } \\
\pi \text {-A isotherm }\end{array}$ & $\begin{array}{l}\text { Quantification of } \\
\text { the strength of } \\
\text { interaction } \\
\text { Follow-up with time } \\
\text { possible } \\
\text { Extraction of lipids } \\
\text { by the protein } \\
\text { visible }\end{array}$ & $\begin{array}{l}\text { Easy to perform, monolayers far from } \\
\text { real system }\end{array}$ & {$[17,18]$} \\
\hline $\begin{array}{l}\text { Isothermal } \\
\text { calorimetry (ITC) }\end{array}$ & $\begin{array}{l}\text { Calorimetric } \\
\text { characterization } \\
\text { upon mixing the two } \\
\text { interacting } \\
\text { components }\end{array}$ & $\begin{array}{l}\text { Quantification of } \\
\text { thermodynamic } \\
\text { parameters }\end{array}$ & $\begin{array}{l}\text { Access to quantified information, Low- } \\
\text { energy interactions difficult to } \\
\text { characterize } \\
\text { Need to be sure of the chosen models } \\
\text { for extracting the parameters }\end{array}$ & {$[21-24]$} \\
\hline $\begin{array}{l}\text { Neutron or X-ray } \\
\text { scattering and } \\
\text { diffraction }\end{array}$ & $\begin{array}{l}\text { Elastic and inelastic } \\
\text { scattering, } \\
\text { diffraction of beam } \\
\text { linked to 3D and 2D } \\
\text { features of the } \\
\text { sample }\end{array}$ & $\begin{array}{l}\text { Size and shape of } \\
\text { vesicles, size of the } \\
\text { organized domains, } \\
\text { diffusion coefficient } \\
\text { and bilayer bending } \\
\text { elasticity }\end{array}$ & $\begin{array}{l}\text { A very broad scale length accessible } \\
\text { from few } \AA \text { (diffraction) to hundreds of } \\
\mathrm{nm} \text { (scattering). It can be performed on } \\
\text { vesicles, supported bilayers and } \\
\text { monolayers at the air/water interphase, } \\
\text { neutrons performed only in } \\
\text { international infrastructures, lipid } \\
\text { deuteration can be necessary. To get } \\
\text { rich information needs specialists. }\end{array}$ & [56-63] \\
\hline $\begin{array}{l}\text { Static and dynamic } \\
\text { light scattering } \\
\text { MALS and DLS / } \\
\text { Zeta potential } \\
\text { measurement }\end{array}$ & $\begin{array}{l}\text { Brownian motion of } \\
\text { light scattering } \\
\text { systems linked to } \\
\text { their size }\end{array}$ & $\begin{array}{l}\text { Size of the } \\
\text { scattering object } \\
\text { Molar mass, } \\
\text { Aggregation } \\
\text { number }\end{array}$ & $\begin{array}{l}\text { Interaction visible through the } \\
\text { dynamics change, extraction of } \\
\text { information linked to mathematical } \\
\text { models whose validation is difficult } \\
\text { Very difficult extraction in case of } \\
\text { mixtures of different species. }\end{array}$ & [7] \\
\hline Conductimetry & $\begin{array}{l}\text { Conductimetry of } \\
\text { compartments } \\
\text { different with ion } \\
\text { content }\end{array}$ & $\begin{array}{l}\text { Identification of } \\
\text { channel formation } \\
\text { through a } \\
\text { membrane }\end{array}$ & Information on channel formation & $\begin{array}{l}{[48,50,5} \\
1]\end{array}$ \\
\hline
\end{tabular}


Electron

Paramagnetic (or

spin) Resonance

(EPR)
Measurement of $\quad$ Information on

magnetic properties interacting site

of radical molecules (location) and

conformation.
Requires a labelling of protein/lipid

with spin-traps
$[7,31,32]$ 